По-друге, релігійним громадам потрібні кадри священнослужителів, яких в достатній кількості не можуть підготувати духовні заклади. Тому, паралельно із державною, повинна виникнути мережа релігійної (богословської) освіти.

По-третє, експеримент, який проводиться в Чернівецькому національному університеті, показав, що настав час співробітництва науковців і теологів, а це уможливлює поєднання взаємодоповнення зусиль освітян та формування міцного духовно-ціннісного потенціалу українського суспільства.

Подальша демократизація суспільства повинна призвести до того, що на Буковині виникне ще ряд шкіл як при релігійних громадах, так $\mathrm{i}$ публічних, а пропаганда ворожості між державною освітою та релігійною зникне сама по собі.

\title{
Колонова $A$.
}

\section{НЕ БОЯТИСЯ ЗНАНЬ}

Згідно з вказівкою Президента України з 1 вересня в усіх школах України мав 3'явитися новий предмет - християнська етика або етика віри (остаточної назви поки що немає). Заяви про його створення, які лунали до прийняття цього розпорядження, сприймалися далеко неоднозначно. Багато людей і тепер висловлюються проти викладання в школі «такої делікатної дисципліни»: одні ставляться до неї з обуренням, інші - стриманіше, але все ж таки скептично. I така ситуація виглядає дивною $з$ кількох причин. Інколи складається враження, що люди, які наприкінці минулого року самі розпочали зміни у своїй країні, тепер прагнуть відступити назад, закритися руками від нових пропозицій, навіть не міркуючи, у чому ці пропозиції полягають. А тому, не роздивившись, відразу наводять цілу купу аргументів проти нового предмета.

Найбільшою перешкодою впровадженню в школах християнської етики називають існування в Україні багатьох конфесій. Через це, мовляв, вчителі священики будуть необ'єктивними у трактуванні деяких релігійних аспектів, намагаючись подати їх кожен 3 позиції власного патріархату. Але скажіть, чому така проблема не постає у зв'язку 3 викладанням інших гуманітарних («неточних») наук, таких як література, історія тощо? Здавалося б, тут повинна виникати ще більша плутанина, 
бо кожен вчитель може по своєму оцінювати художнійтвір чи історичну подію. Однак у той же час існує єдина програма і підручник, цією програмою затверджений, а тому немає небезпеки в нав'язуванні вчителем однієї думки.

Другий аргумент «проти»: за один-два місяці неможливо виробити якісну навчальну програму, а також написати підручник, а відтак новий предмет будуть викладати некваліфіковано.

Але ж відомо, що в кількох Західних областях України християнська етика викладається вже десять років, тобто досвід запровадження такої дисципліни вже $\epsilon$.

Багато хто вважає недоречним викладання християнської етики в школі через те, що Церква в Україні відокремлена від держави, а школа - від Церкви. Відповідно, церковною освітою повинні займатися спеціальні недільні школи, куди можна ходити за власним бажанням.

Однак, зі слів міністра освіти і науки Станіслава Ніколаєнка, новий предмет не ставить перед собою завдання примусити дитину вірити у християнські догми. Мета його, як і будь якого іншого курсу, дати інформацію про частину нашої дійсності. Людина може бути атеїстом, але їй, як освіченій особі, потрібно знати, що таке релігія, від якої вона прагне відсторонитися. Крім того, на мою думку, впровадження християнської етики саме як одного із загальноосвітніх предметів могло б принести неабияку користь, адже ці знання стали б гарним доповненням до інших шкільних курсів. Йдеться передусім про гуманітарні предмети (історія, естетика, культурологія, людина і суспільство). До того ж, без основ християнської етики неможливо повною мірою осягнути своєрідність української літератури, ії витоки, основні мотиви, які дуже відрізняються від мотивів інших світових літератур саме завдяки потужному впливу християнської моралі на українське письменство.

Цікаво, що згідно із соціологічними опитуваннями, які проводилися цього року напередодні Великодня, більш ніж 80\% українців вважають себе віруючими. Отже, за 70 років радянської атеїстичної пропаганди зі свідомості нашого народу не вдалося викоренити християнської віри, а відтак нова дисципліна прийде не на мертвий грунт. 3 іншого боку, вона допоможе отримати знання, яких на сьогодні замало навіть у віруючих людей.

Мушу додати, що аргументи проти введення нового предмета частіше наводять саме представники старшого покоління, виховані як «професійні» атеїсти за часів СРСР. Серед думок, які я чула, була, наприклад, така: релігія - це, по-перше, омана, а по-друге - справа минулого, а ми повинні йти у майбутнє. Підхоплюю останню частину 
цього висловлювання і додаю від себе: якщо ми йдемо в майбутнє, то повинні не боятися знань, тим більше таких, що несуть у собі духовність. Адже від знань ще нікому на Землі не було шкоди.

Стаття із газети «День» за 20 серпня.

Сверстюк $\boldsymbol{C}$.

\section{ПРО ХРИСТИЯНСЬКУ ЕТИКУ В ШКОЛІ}

Конституційне положення про відокремлення Церкви від держави вже має понад 200 років. Нині посилаються на нього, вже не пам'ятаючи, як воно виникло. Справа в тому, що Французька революція 1789 року мала антифеодальний і антиклерикальний характер. Вона відокремлювала справи державні від церковних, щоб єпископи й кардинали керували Церквою, а не державою. Революція 1917 року в Росії також розривала тріумвірат “саомдержавіє, православіє, народность”. Держава й Церква мали існувати порізно. Більшевики відкинули стару державу й Церкву, але в своє законодавство 1919 року Декретом записали відокремлення Церкви від держави й школи від Церкви. Оскільки право, мораль і релігію вони уневажнили, а державу абсолютизували, то держава, а особливо іiі каральні органи, топтала й мораль, і етику, й релігію, і священнослужителів, і їхніх захисників...

Ці неписані закони ввійшли в звичку чотирьох поколінь, i частокіл між школою й Церквою або між Церквами різних конфесій виростає в злих або заляканих очах. Сердитий директор марить про китайський мур, щоб діти не перелізли на церковне подвір'я. Сердитий піп відгороджується від дітей і від громади, гуртуючи коло себе сердиту прицерковну челядь...

А все це - “продукт епохи". У нормальному світі не повинно так бути. В доброму світі вчитель ходить до Церкви і заохочує ходити дітей. I то не тільки тому, що з такими дітьми виникає близькість і спільна мова. Діти, чутливі до священного тексту, будуть чутливими й до художнього тексту. Дітям, які знають молитву, не треба ставити частоколів. Вони чують тихий голос і їм не треба, як у курсі посткомуністичної схоластики під назвою “етика", пояснювати “відтворення самовизначення особистісного “Я” дитини в розмаїтості стосунків зі світом". Вчитель скаже дитині просто: “Треба любити! Починай від дому, і тоді маєш 